\title{
Social Perception and Supply of Ecosystem Services - A Watershed Approach for Carbon Related Ecosystem Services
}

\author{
Antonio J. Castro, Caryn C. Vaughn, Jason P. Julian, \\ Marina García Llorente and Kelsey N. Bowman \\ Additional information is available at the end of the chapter
}

http://dx.doi.org/10.5772/59280

\section{Introduction}

Over the past two decades research on ecosystem services, i.e. the benefits that humans derive from natural systems [1], has gained importance among scientists, managers, and policymakers worldwide as a way to communicate societal dependence on ecological life support systems integrating both natural and social science perspectives [2]. Ecosystem services can be direct benefits, such as food or freshwater for drinking, or indirect benefits through provisioning of services such as carbon sequestration [1]. Ecosystem services include 1) provisioning services obtained directly from the ecosystem such as food provision, 2) regulating services such as water regulation, habitat, air quality, and water quality, and 3) cultural services, which are the benefits that people obtain through tourism, aesthetic values, spiritual enrichment, and sense of place [3, 4].

The ecosystem services approach is useful for decision-making in conservation and natural resource management [5] because it assigns value to nature by translating ecosystem properties into human needs [6]. Ecosystem services can be valued using different approaches ranging from biophysical quantifications to sociocultural surveys to economic assessment. Biophysical quantification of services such as carbon storage and sequestration have recently been used extensively in conservation applications. However, to conserve biodiversity, we need to move beyond narrow studies of species or habitat status and increase social awareness of the broader importance of conservation [2]. A key challenge in implementing this approach is identifying an ecosystem's capacity to provide services (supply side) and the social demand for those services (demand side). Addressing both the supply and demand for ecosystem 
services underscores the fact that the importance of an ecosystem service to people is influenced not only by the ecosystem's properties but also by societies need for that service and how that need is perceived.

The Kiamichi River watershed, in southeastern Oklahoma (USA), provides many direct and indirect ecosystem services to stakeholders that live in or visit the area. This watershed and the area surrounding it is a national biodiversity hotspot, meaning it is biologically rich, yet threatened. This area is also at the center of a highly politicized debate between different stakeholders' plans for the use of the watershed's ecosystem services and activities that may affect those services [7]. The Kiamichi watershed not only provides many important freshwater services (e.g., drinking water, water filtration or recreation), but it provides numerous terrestrial ecosystem services as well such as habitat for species and food production. The land is relatively undeveloped with few urban areas and extensive tracts of second growth, forested landscapes [8] that provide carbon storage and sequestration. Carbon sequestration is considered an optimal descriptor of ecosystem functioning [9, 10, 11]. It is a current focus in climate change studies and is classified as an intermediate service [12] or as supporting the delivery of other regulating services [13]. Most people are unaware that carbon sequestration provides direct benefits such as erosion control and soil fertility and indirect benefits such as air quality and habitat for species.

Here, we used the Kiamichi River watershed as a case study to examine the social perception and biophysical supply of carbon related services. We first assessed the social perception of the general public regarding a variety of ecosystem services provided by the Kiamichi watershed in southeastern Oklahoma, including direct and indirect benefits related to the carbon cycle. We used a carbon sequestration model to quantify the spatial distribution of carbon storage and sequestration across the watershed. We used these results along with the social perception of services and the watershed capacity for carbon sequestration to analyze the supply-demand framework of ecosystem services [14]. Finally, we discuss the implications for linking the structure and functioning of biodiversity within the watershed.

\section{Problem statement}

Changes in land use-land cover are recognized as one of the most important direct drivers in ecosystem services delivery [15]. Landscapes across the U.S. are changing with human population growth and increased development. These land use changes alter the natural sinks and pools of carbon in the environment, but are often not included in land management or planning. Different land use types and dominant vegetation differ in their storage capacity and sequestration rate [15]. To better understand the impacts of land cover-use changes in relatively undeveloped areas such as the Kiamichi watershed, research is needed on different land uses and land changes and their impacts on carbon storage and sequestration.

Carbon sequestration can be viewed as an optimal descriptor of ecosystem functioning [10,11], and human-derived carbon fluctuations [16] in the atmosphere affect many other services such as air quality and biomass production. Changes in air quality are one of the carbon related 
ecosystem services that is most easily recognized by the public. Thus, understanding how the public perceives the status and importance of air quality can help inform resource management. Our study compares perceptions of Kiamichi watershed stakeholders with the actual state of carbon sequestration services and land use practices in the watershed.

\section{Application area}

The Kiamichi River watershed in southeastern Oklahoma, with a drainage area of 4,650 km², is a major tributary of the Red River, which flows into the Mississippi River and Gulf of Mexico (Figure 1). The watershed is $64 \%$ forest, $18 \%$ pasture, $11 \%$ grassland/shrubland, $3 \%$ urban, $3 \%$ open water, and 1\% wetlands according to the 2006 National Land Cover Dataset. While most of the watershed is temperate deciduous forest (primarily oak-hickory), there are several conifer plantation forests across the watershed. Its steep and rugged terrain has limited major row crop agriculture, there are no nearby major cities or interstates, and human population density is low [5.6 people $/ \mathrm{km}^{2}$ ] [17]. This lack of development in the watershed has left the Kiamichi River with relatively pristine water and high aquatic biodiversity, containing 86 fish species and 31 mussel species, three of which are federally endangered $[18,19,17,20]$.

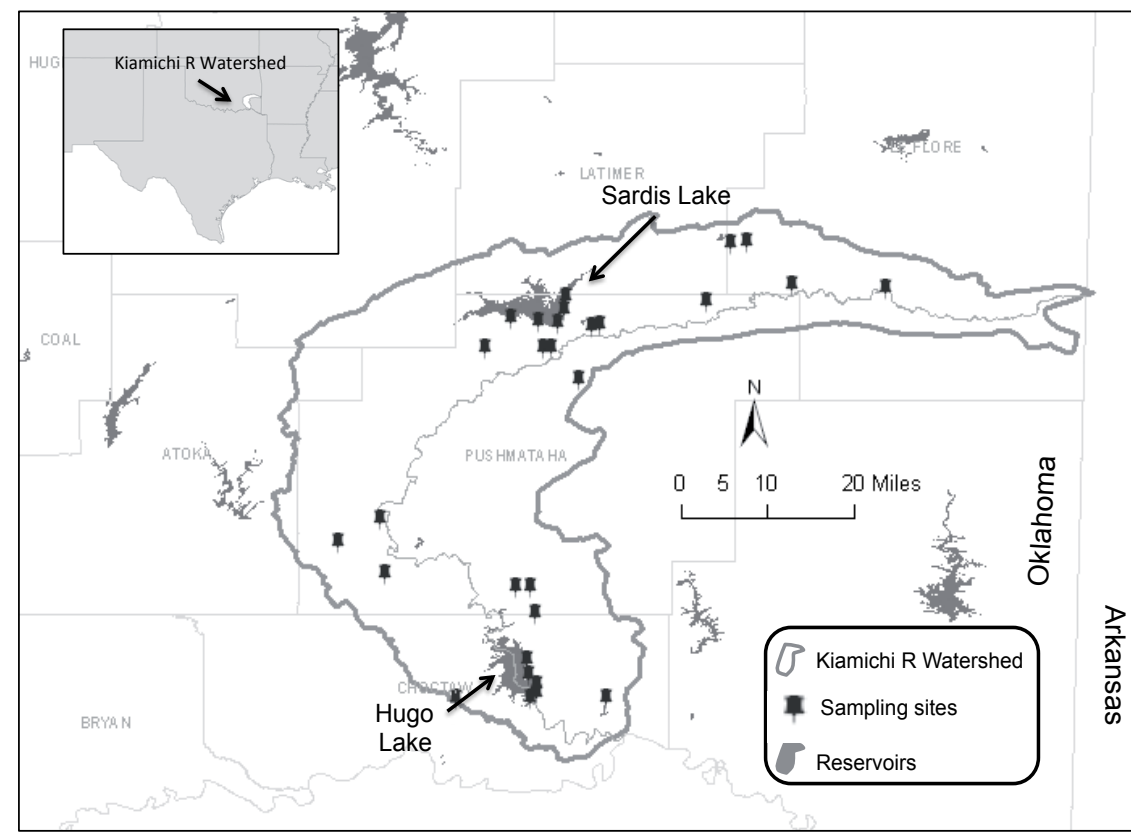

Figure 1. Kiamichi River watershed study area and sampling sites. 


\section{Method used}

\subsection{Social sampling and analysis of perceptions of ecosystem services}

We conducted social sampling regarding public perceptions of a suite of ecosystem services provided by the Kiamichi watershed. In summer 2013, we conducted 304 random, individual, face-to-face surveys across the watershed. Interviewees included stakeholders residing in the watershed, tourists, and people working within the watershed. Sampling was conducted at 30 sites in the watershed (Figure 1). Social preferences regarding the variety of ecosystem services provided by the Kiamichi River were explored through ranking [21]. Our study included eight categories of carbon-and water-related ecosystem services in three classes: provisioning (freshwater provision), regulating (water regulation, water quality, air quality, and habitat for species), and cultural services (recreation, cultural heritage, and local identity). We asked interviewees if they felt that the Kiamichi River provided benefits that contribute to human well being (very much, much, not very much, and nothing), and asked them to provide examples of potential benefits. All respondents were asked to indicate the relative importance and perceived trend of each service over the last 10 years. To do this, they were asked to select the four services most important to them and to rank them from 1 to 4 (important to essential services). From this information, we created an ordinal measure of the importance of each service to each respondent [22].

\subsection{Mapping the distribution of carbon storage and sequestration}

To model carbon storage we used InVEST (Integrated Valuation of Environmental Services and Tradeoffs). InVEST is a family of GIS tools designed by the Natural Capital Project to inform decisions about natural resource management and provides an effective tool for evaluating trade-offs among ecosystem services under different scenarios [23]. InVEST models are spatially explicit and return results in either biophysical (e.g., tons of carbon stored) or economic terms (e.g., net present value of that sequestered carbon). We used the InVEST carbon sequestration model to quantify and map the current (i.e., 2006) spatial distribution of carbon sequestration across the Kiamichi watershed. Here, the carbon model estimates for each pixel (30-meter resolution) a value that represents the change in storage between two time periods. Negative values represent a loss in carbon sequestering capacity, and positive values represent areas that have gained more capacity to sequester carbon.

We used InVEST Terrestrial Toolboxes (version 2.5.6) in ArcMap (10.2) to generate a map of the balance of carbon sequestration in the Kiamichi watershed. The model needs several inputs to successfully estimate carbon sequestration including land use-land cover (LULC) maps for the two years of comparison and data on each LULC's capacity to stock carbon in four fundamental carbon pools: above ground biomass, below ground biomass, soil, and dead matter. These data can be collected from real time monitoring of carbon levels or from the literature. We obtained carbon pool values from the 2006 IPPC Guidelines for National Greenhouse Gas Inventories report by the Intergovernmental Panel on Climate Change 
[24]. According to this source, southeastern Oklahoma is considered a subtropical steppe climate. Estimated carbon values for LULC types for a subtropical steppe climate were derived from various IPCC tables in Volume 4 of the report. For the five LULC types selected we calculated the mean value when multiple values were available. Not all four of the required carbon pools were listed for each LULC category in the IPCC report; so additional literature searches were conducted $[25,26]$. Finally, all carbon pool values were converted into metric tons (or Mega grams) per hectare $\left(\mathrm{Mg} \mathrm{ha}^{-1}\right)$ and formatted in a table, as per InVEST model requirements.

\subsection{Land use-Land Cover (LULC) maps}

We compared changes in LULC between 1898 and 2006. The LULC map for 1898 is the earliest complete data set for the Kiamichi watershed and served as the reference year for the carbon model. LULC in 1898 largely represents the potential natural vegetation and pre-European landscape of southeastern Oklahoma [27]. We created the 1898 LULC map using data from [28], which was derived from Public Land Survey System records made available by the Bureau of Land Management's General Land Office. Our 1898 map included four LULC categories: cropland, forest, grassland, and wetland. The 2006 LULC map was derived from the National Land Cover Database [29], which contained over twenty LULC categories. To make the two datasets compatible with each other and InVEST, we grouped LULC as follows: Urban-Barren, Water-Wetland, Forest, Shrub-Grassland-Pasture, and Cropland. The 1898 dataset was converted to a 30-meter raster to match the 2006 NLCD.

\section{Status and results}

\subsection{Social perception of watershed services}

Of the 304 respondents, 300 (99\%) answered that the Kiamichi River is "providing benefits that are contributing to human wellbeing," with $86 \%$ answering that it provides substantial benefits (i.e., very much, Figure 2a). Only one respondent said that no benefits were provided by the Kiamichi, and three respondents did not answer the question. When asked to give an example of a benefit provided by the Kiamichi, virtually all of those who responded gave an example related to water resources (i.e., drinking water, fishing, recreation). Air quality was not mentioned by any of the respondents as a watershed benefit.

The ecosystem service with the highest average importance among all respondents was habitat for species, followed by recreation and water quality (Figure 2b). Ecosystem services considered less important were local identity, followed by cultural heritage and air quality. Most respondents thought that many of the services they considered most important to human wellbeing (habitat for species and water quality) had declined, while those services that were not considered as important (cultural heritage and local identity) had remained stable or increased (Figure 3). Air quality was considered to be the most stable ecosystem service. 

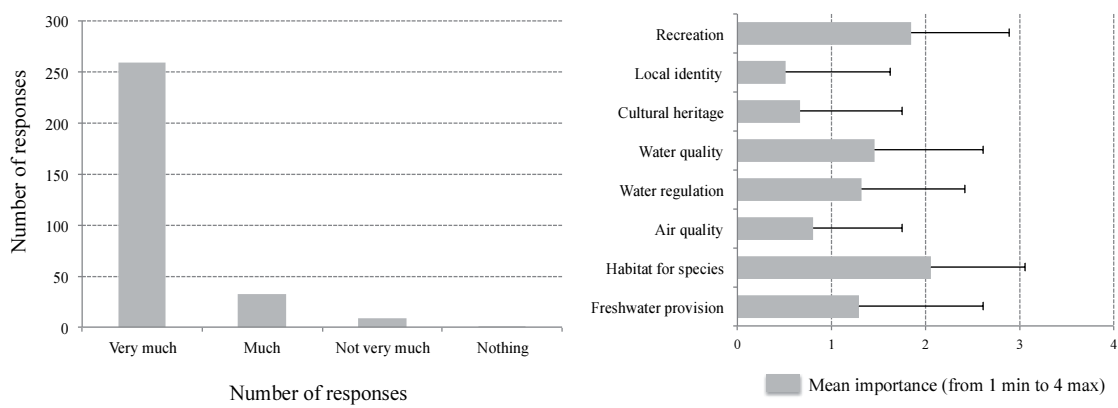

Figure 2. Perception of Kiamichi watershed benefits and social importance of supplied ecosystem services

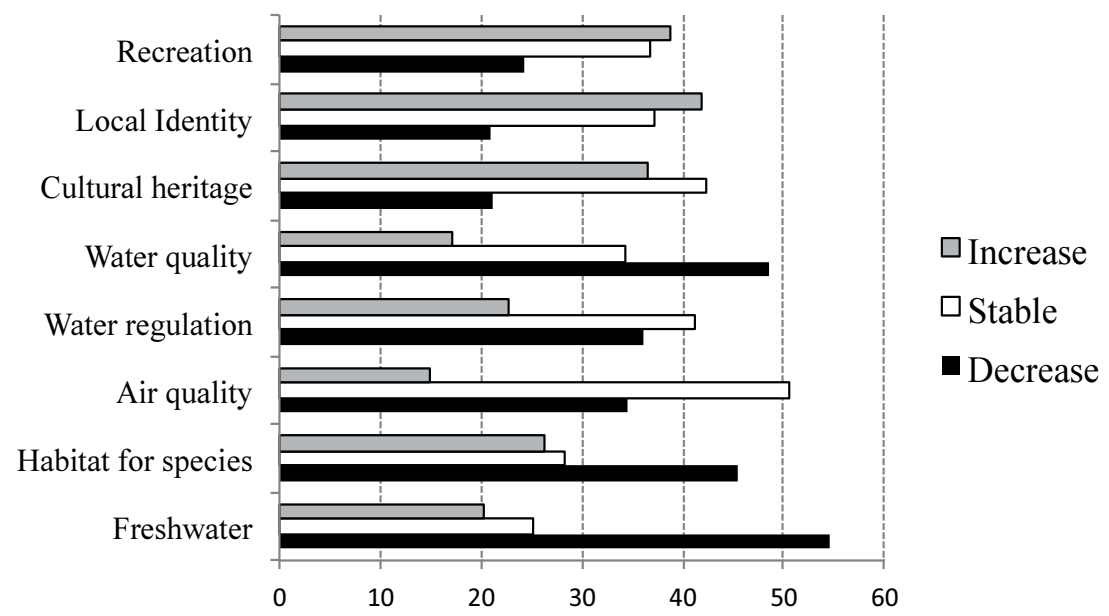

Population (\%)

Figure 3. Ecosystem services trends in the Kiamichi Watershed.

\subsection{Land use-Land Cover (LULC) change between 1898 and 2006}

Changes in LULC between 1898 and 2006 are important to understanding the carbon sequestration balance in the Kiamichi watershed. To run the sequestration model, LULC datasets for 1898 and 2006 were reclassified into five categories: urban-barren, cropland, forest, shrubgrassland-pasture, and water-wetland (Figure 4). In 1898, 93.9\% of the Kiamichi watershed was covered in forest, and $5.4 \%$ was covered in shrubland, grassland, and pasture. Only a fraction of a percent of the land was covered by cropland $(0.6 \%)$ or water-wetland $(0.1 \%)$. In 2006 , the Kiamichi watershed represented a rural landscape, with many of the forests replaced with 
pastures. The $30.3 \%$ decline in forest was largely accounted for by the $23.6 \%$ increase in shrubgrassland-pasture. Urban development (via 4 small towns) and water reservoir creation (via two large dams) accounted for the rest of the lost forests. Between 1898 and 2006, cropland decreased from $0.6 \%$ to $0.1 \%$.
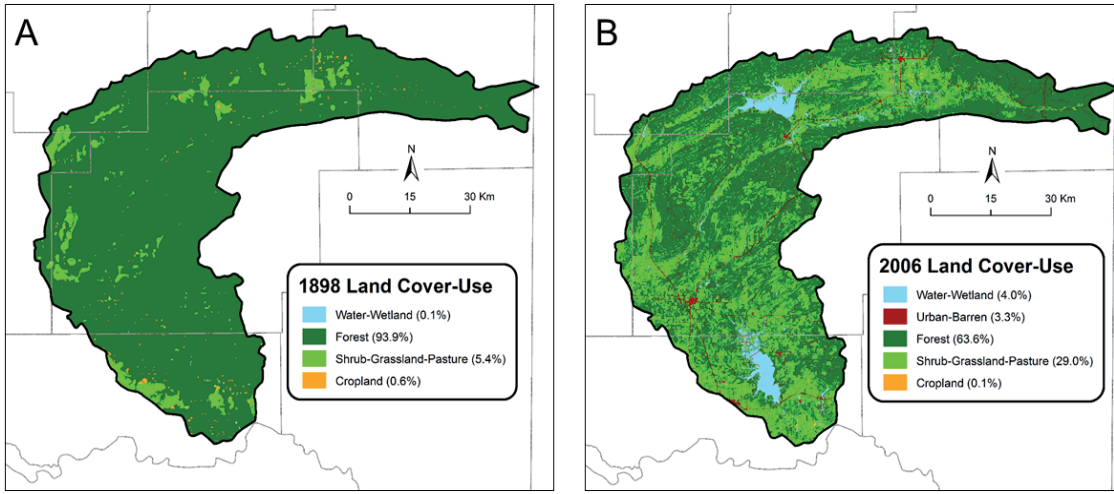

Figure 4. Land cover-use maps for the Kiamichi River watershed in southeastern Oklahoma for 1898 (A) and 2006 (B). Oklahoma county boundaries are included for reference.

\subsection{Carbon storage and sequestration in the Kiamichi watershed}

Based on carbon stocks data collected for each LULC type (Table 1), we observed a significant decrease between 1898 and 2006 in the capacity of the watershed to store carbon (Figure 5ab). Because of this, there are areas, mostly in the upper and lower basin, where the conversion of forests to shrub-grassland-pastures produced a decrease of total carbon storage (Figure 5B). This involved a reduction in the aboveground and soil stocks, producing a difference of over $30 \mathrm{Mg} \mathrm{ha}^{-1}$ of carbon per hectare in both the aboveground and soil carbon stocks.

\begin{tabular}{ccccc}
\hline Land use-land cover & $\begin{array}{c}\text { Above ground } \\
\text { biomass }\end{array}$ & Below ground biomass & Soil & Dead matter \\
\hline Cropland & 1.67 & 4.52 & 17.80 & 0.00 \\
\hline Forest & 37.60 & 7.52 & 48.50 & 3.45 \\
\hline Shrub-Grassland-Pasture & 1.27 & 5.08 & 24.05 & 0.13 \\
\hline Water-Wetland & 0.00 & 0.00 & 68.25 & 0.15 \\
\hline Urban-Barren & 0.00 & 0.00 & 0.00 & 0.00 \\
\hline
\end{tabular}

Table 1. Carbon stock related to the four carbon pools required for the InVEST carbon model. Data are converted into metric tons of carbon per hectare $\left(\mathrm{Mg} \mathrm{ha}^{-1}\right)$ 
The results from the carbon model output clearly show an overall trend of decreasing and null carbon sequestration in most of the Kiamichi watershed (Figure 5c). Considering the positive and negative carbon sequestration estimations, the carbon model obtains a watershed total of 9.197.087 metric tons of carbon. This result shows that the watershed stored 9.1 million less metric tons of carbon in 2006 than it did in 1898. There are small patches of positive carbon sequestration (green area in Figure 5c) due to recent reforestations around Sardis and Hugo reservoirs. The areas experiencing the most negative carbon sequestration (red area in Figure 5c) are those areas converted from forest and grasslands into urban-barren land. The lower watershed area has experienced the most loss of carbon sequestration capacity. One explanation for this pattern of agricultural land conversion is that the lower watershed is flatter and more suitable for pasture while the steeper slopes of the upper watershed limit pasture development. However, there is still a loss in sequestration as the forested mountain slopes are being thinned for timber production.
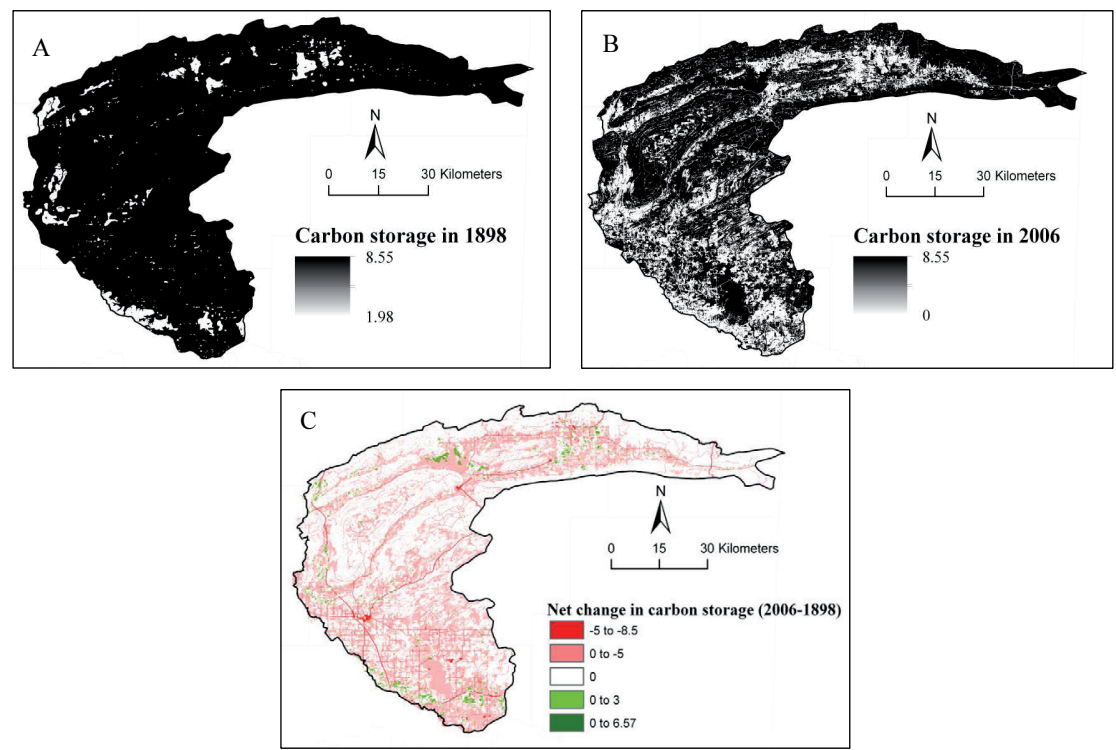

Figure 5. Maps of carbon storage in 1898 (A) and 2006 (B), and net change in carbon storage during this period (C) for the Kiamichi River watershed. Positive values indicate a net-gain in carbon sequestration (e.g., cropland to forest), whereas negative values indicate lost carbon sequestration (e.g., forest to pasture). The values are in $\mathrm{Mg} / \mathrm{km}^{2}$.

\section{Conclusions}

Conserving ecological processes is necessary to maintain human wellbeing. The ecosystems services approach allows for quantification of the importance of ecological processes to 
humans. Such quantification should include multiple dimensions including biophysical, sociocultural and economic valuations. Our study provides a multidimensional valuation of carbonand water-related ecosystem services in a large rural watershed. Carbon sequestration is an optimal ecosystem service because it ensures the supply of other ecosystem services such as food production, green areas for recreation and better air quality $[13,11]$. Our results show that people living in the watershed think the area provides ecosystem services, but that air quality is not as important as services such as habitat for species, water quality, and recreation. Ecosystem services associated with water resources are highly visible (i.e. water availability, recreation on lakes) and these are the most highly valued by our survey respondents. Unlike water related services, air quality is less tangible and difficult for people to visualize in areas without heavy air pollution. However, changes in carbon storage (the watershed lost the capacity to store and sequester 9.1 million metric tons of carbon since 1898) reflect conversion of natural forests into agricultural lands or timber production stands. Stakeholders in the watershed need to understand that in the long term, continuing this land conversion trend will decrease carbon sequestration and potentially air quality. We think our novel, multidimensional approach combining both biophysical supply and social perception of carbon related ecosystem services will help stakeholders and managers make more informed land use decisions in the future.

For future research, as climate change and human development continue to interact and affect the delivery of ecosystem services, other valuation practices including mapping the biophysical supply of other ecosystem services such as biodiversity conservation or water regulation will provide practical results for landscape management and planning. Currently, other mapping tools such as the Artificial Intelligence for Ecosystem Services (ARIES) [30] or POLYSCAPE [31] are applied to landscapes of all sizes and are expected to work well with each unique scenario [2]. Many researchers in the field of biology, ecology, and environmental studies are calling for a focus on multidimensional approaches that include both a natural valuation component along with a social one [28].

\section{Study limitations, assumptions, and future work}

There were limitations to this study and assumptions made for the InVEST model. Regrouping and simplifying LULC classes obviously generalized carbon storage losses/gains. When reclassifying the 2006 LULC map, some reclassifications were obvious by the descriptions, but some others required assumptions. For example, those LULC types classified as Central OakHardwood and Pine Forest by the National Vegetation Classification were reclassified into simply Forest. Reclassification of other National Vegetation Classification LULCs, such as Recently Disturbed or Modified were assumed, and requires further investigations.

Carbon pool data collection also presented some challenges. Because the available IPCC carbon data values were based on broadly generalized values for each climate division, many assumptions were made as to vegetation types in the area. In this sense, further research for carbon pools for each dominant vegetation species per LULC is needed to obtain a value that is more indicative of the watershed itself, not just the climate region. 
Further, this study only looked at two years to derive carbon storage estimates. Southeastern Oklahoma is a dynamic landscape that can change at monthly and annual timescales due to timber harvesting, fire, drought, and insect infestations [32]. Some studies have characterized this region as having one of the highest annual rates of land cover change in the U.S. [33] and as being one of the most sensitive to climate change [34]. If we want to capture these land cover changes at higher spatio-temporal resolutions, new techniques will be needed [e.g., 32, 35]. These frequent and intense changes to forest cover have many implications for carbon storage dynamics, which was also beyond the scope of our study.

\section{Acknowledgements}

We thank all of the people in the Kiamichi watershed that kindly responded to the questionnaire. We thank Melanie Lawson and Joseph Sardasti for assisting in fieldwork, and Bruce Hoagland and Todd Fagin for assisting in land use-land cover maps. This research is based on work partially funded by The University of Oklahoma through the Oklahoma Biological Survey and the South Central Climate Science Center.

\section{Author details}

Antonio J. Castro ${ }^{1 *}$, Caryn C. Vaughn ${ }^{1}$, Jason P. Julian², Marina García Llorente ${ }^{3}$ and Kelsey N. Bowman ${ }^{4}$

*Address all correspondence to: acastro@ou.edu

1 Oklahoma Biological Survey, Department of Biology and Ecology and Evolutionary Biology Graduate Program, University of Oklahoma, Norman, OK, USA

2 Department of Geography, Texas State University, San Marcos, TX, USA

3 Sociology of Climate Change and Sustainable Development research group, Department of Social Analysis, University Carlos III, Madrid, Spain

4 Department of Geography and Environmental Sustainability, University of Oklahoma, USA

\section{References}

[1] Daily G, Alexander S, Ehrlich, P, Goulder L, Lubchenco J, Matson P, Woodwell G. Ecosystem Services: Benefits Supplied to Human Societies by Natural Ecosystems. Issues in Ecology; 1997. 
[2] Castro A, Garcia-Llorente M, Martin-Lopez B, Palomo I, Iniesta-Arandia I. Multidimensional approaches in ecosystem services assessment. In: Earth Observation of Ecosystem Services, 2013a. 441-468.

[3] Perrings C, Naeem S, Ahrestani, FS, Bunker E, Burkill P, Canziani G, Elmqvist T, Fuhrman JA, Jaksic FM, Kawabata Z, Kinzig A, Mace GM, Mooney HM, Prieur-Richard AH, Tschirhart J, Weisser A.. Ecosystem services, targets, and indicators for the conservation and sustainable use of biodiversity. Frontiers in Ecology and the Environment 2011;9:512-520

[4] Wainger L, Mazzotta M. Realizing the potential of ecosystem services: A framework for relating ecological changes to economic benefits Environmental Management 2011;48:710-733.

[5] Harrison PA. Ecosystem services and biodiversity conservation: an introduction to the RUBICODE project. Biodiversity Conservation 2010;19:2767-2772

[6] Castro AJ, Martín-López B, García-Llorente M, Aguilera PA, López E, Cabello J. Social preferences regarding the delivery of ecosystem services in a semiarid Mediterranean región. Journal of Arid Environment 2011;75:1201-1208

[7] Oklahoma Water Resources Board vs. Choctaw and Chickasaw Nations of Oklahoma. Oklahoma Supreme Court, case 110375. 2012.

[8] Mast M, Turk J. Environmental characteristics and water quality of Hydrologic Benchmark Network stations in the West-Central United States, 1963-95. U.S. Geological Survey Circular. 1999.

[9] Castro AJ, Paruelo JM, Alcaraz-Segura D, Cabello J, Oyarzabal M, López-Carrique E. Missing gaps in the estimation of the carbon gains service from Light Use Efficiency models In: Alcaraz-Segura, Di Bella, C., D. (Eds). Earth Observation of Ecosystem Services, 2013b.105-124

[10] Paruelo JM, Piñeiro G, Baldi G, Baeza S, Lezama F, Altesor AI, Oesterheld M. Carbon Stocks and Fluxes in Rangelands of the Río de la Plata Basin. Rangeland Ecosystem Management 2009;63.94-108.

[11] Cabello J, Fernández N, Alcaraz-Segura D, Oyonarte C, Piñeiro G, Altesor A, Delibes M, Paruelo JM. The Ecosystem Functioning Dimension in Conservation: insights from remote sensing. Biodiversity and Conservation 2012;21:3287-3305.

[12] Fisher B, Turner RK, Morling P. Defining and classifying ecosystem services for decision making. Ecological Economics, 2008;643-653.

[13] (MA) Millennium Ecosystem Assessment. Washington, DC: Island Press 2005.

[14] Martín-López BE, Gómez-Baggethun M, García-Llorente M, Montes C. Trade-offs across value-domains in ecosystem services assessment. Ecological Indicators 2014;37:220-228 
[15] Vitousek PM, Mooney HA, Lubchenco J, Melillo JM. Human domination of Earth's ecosystems. Science 1997;277(5325), 494

[16] Alcaraz-Segura D, Paruelo JM, Epstein HE, Cabello J. Environmental and Human Controls of Ecosystem Functional Diversity in Temperate South America. Remote Sensing 2013;5(1):127-154

[17] Matthews WJ, Vaughn CC, Gido, KB, Marsh-Matthews E. Southern plains rivers, In: Rivers of North America, eds A. Benke, C.E. Cushing. Academic Press 2005.

[18] Vaughn CC, and M. Pyron Population ecology of the endangered Ouachita Rock Pocketbook mussel, Arkansia wheeleri (Bivalvia: Unionidae), in the Kiamichi River, Oklahoma. American Malacological Bulletin 1995;11:145-151.

[19] Vaughn CC, 2000. Changes in the mussel fauna of the Red River drainage: 1910 present. In: Proceedings of the First Freshwater Mussel Symposium, edited by R. A. Tankersley, D. I. Warmolts, G. T. Watters, B. J. Armitage, P. D. Johnson, and R. S. Butler, Ohio Biological Survey, pp. 225-232 Columbus, Ohio.

[20] Galbraith HS, Spooner DE, Vaughn CC. Status of rare and endangered freshwater mussels in southeastern Oklahoma rivers. Southwestern Naturalist 2008;53: 45-50.

[21] Agbenyega O, Burgess PJ, Cook M, Morris J. Application of an ecosystem function framework to perceptions of community woodlands. Land Use Policy 2009;26:551-557

[22] Winkler R. Valuation of ecosystem goods and services, An integrated dynamic approach. Ecological Economics 2006;59:82-93

[23] Nelson E, Sander H, Hawthorne P, Conte M, Ennaanay D. Projecting Global LandUse Change and Its Effect on Ecosystem Service Provision and Biodiversity with Simple Models. PLoS ONE 2010;5(12): e14327. doi:10.1371/journal.pone.0014327

[24] Eggleston S, Buendia L, Miwa, K, Ngara T, Tanabe K. IPCC Guidelines for National Greenhouse Gas Inventories, Volumen 4. Japan: Institute for Global Environmental Strategies. 2006.

[25] Potter KN, Derner JD. Soil carbon pools in central Texas: Prairies, restored grasslands, and croplands. Soil Water Conservation 2006;124-128.

[26] Smith J, Heath L, Skog K, Birdsey R. Methods for calculating forest ecosystem and harvested carbon with standard estimates for forest types of the United States. Newtown Square, PA: US Department of Agriculture 2006.

[27] Goins CR, and Goble D. Historical Atlas of Oklahoma, fourth ed., 286 pp., University of Oklahoma Press, Norman. 2006

[28] Watkins BW. Reconstructing the Choctaw Nation of Oklahoma, 1894-1898: Landscape and Settlement on the Eve of Allotment, 202 pp, Oklahoma State University, Stillwater, 2007 
[29] Fry JG, Xian S, Jin J, Dewitz C, Homer L, Yang C, Barnes N, and J. Wickham. Completion of the 2006 National Land Cover Database for the Conterminous United States. PE\&RS 2011;858-864.

[30] Villa F, Bagstad KJ, Voigt B, Johnson GW, Portela R, Honzak M, Batker D. A methodology for adaptable and robust ecosystem services assessment. PLoS ONE 2014;9(3):e91001.

[31] Jackson B, Timothy P, Sinclair F. Polyscape: A GIS mapping framework providing eficient and spatially explicit landscape-scale valuation of multiple ecosystem services. Landscape and Urban Planning 2013;112:74-88

[32] Tran TV. Measuring land cover change at high spatio-temporal scales, 95 pp, University of Oklahoma; 2013.

[33] Sleeter BM, Sohl TL, Loveland TR, Auch RF, Acevedo W, Drummond MA, Sayler KL, and Stehman SV. Land-cover change in the conterminous United States from 1973 to 2000, Global Environmental Change, 2013;23(4), 733-748

[34] Reker RR, Sayler, KL, Friesz AM, Sohl TL, Bouchard MA, Sleeter BM, Sleeter RR, Wilson TS, Griffith GE, and Knuppe ML. Mapping and modeling of land use and land cover in the eastern United States from 1992 through 2050, in Baseline and projected future carbon storage and greenhouse gas fluxes in ecosystems of the eastern United States: U.S. Geological Survey Professional Paper 1804, edited by Z. Zhu and B. C. Reed, 2014;pp. 27-54.

[35] Jawarneh RN, and Julian JP. Development of an accurate fine-resolution land cover timeline: Little Rock, Arkansas, USA (1857-2006). Applied Geography 2012;35(12)104-113. 
